\title{
SILVER AND GOLD: LOOKING BACK, LOOKING AHEAD
}

\author{
"Where are we headed, oh where have we gone? \\ We've come a long way, now let us move on. \\ Dreams are for dreaming, wake up and they run; \\ Life is for living, come, let us move on ${ }^{\prime \prime}$
}

A quarter of a century ago, Dr. Angel Enriquez en-fleshed for us the opportunity to achieve "immortality in print" at a time when our society was celebrating its silver jubilee. Through the years, our journal has allowed us to disseminate ideas, chronicle discoveries, share knowledge and broadcast our dreams and aspirations beyond the confines of our circles. At the same time, our journal has served as a sounding board, monitoring the pulse of our society and the various contexts in which it lives and breathes and has being. The relationship has been and should rightfully be reciprocal: both journal and society react to and influence each other, while being influenced by and impacting the social, cultural, political, economic and environmental forces in the spatio-temporal contexts in which they exist.

But existence means not merely "being" but "standing-forth." While the various editors in chief have reflected their particular zeitgeists, they likewise stood out, leaving their imprints on the sands of time. For the first eight years, Angel E. Enriquez (1981-1988) nurtured \& cared for his "baby" as editor, advertiser, distributor \& newsboy all rolled into one. Though not surpassed, these efforts were at least equaled by Eusebio E. Llamas (1989-1990), who was succeeded by Alfredo QY Pontejos Jr (1990). Another eight year streak saw untiring efforts to improve the journal and, through it, our society by Joselito C. Jamir (199198), paving the way for Jose M. Acuin (1999-2000) to professionalize the journal, aiming for indexing by Medline and Index Medicus by heroically publishing quarterly issues. The past five years saw Charlotte M. Chiong (2001-2005) at the helm, almost single-handedly performing the herculean task of bringing the journal to where it is today. If there is anything at all to be gleaned from a review of past editorials, it is a humbling, awe-inspiring realization of how each individually made their mark and of how tough an act to follow they collectively are.

As we celebrate the silver anniversary of the Philippine Journal of Otolaryngology Head and Neck Surgery in the golden jubilee year of the Philippine Society of Otolaryngology Head and Neck Surgery, let

\footnotetext{
1"Moving On" Lapeña JF, [unpublished song] Manila:1981.

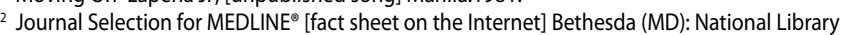
of Medicine (US), 1988 [updated 2005 April 04] Available from: http://www.nlm.nih.gov/pubs/ factsheets/jsel.html.

${ }^{3}$ Thomson Scientific Institute for Scientific Information (ISI) Master Journal List [database on the Internet] Available from: http://www.isinet.com/.

${ }^{4}$ International Committee of Medical Journal Editors. Uniform Requirements for Manuscripts Submitted to Biomedical Journals (N Engl J Med 1997; 336:309-314) [updated February 2006] Available from: http://www.icmje.org/.

${ }^{5}$ Council of Science Editors. Editorial Policy Statements Approved by the CSE Board of Directors. [Printed October 2006] Available from: http://www.councilscienceeditors.org/services.
}

us take the best from the past-- from Dr. Enriquez' dreams to feature "Grand Rounds, Book Reviews, X-ray of the year" to Dr. Chiong's aspirations to include a pathology case review section, review articles, proceedings of meetings, conventions and website publication in this "electronic era" of information technology, let us move on to the future with an internationally peer-reviewed publication that will be someday be indexed in Medline and Index Medicus ${ }^{2}$ and included in the Institute for Scientific Information (ISI) Master Journal list ${ }^{3}$.

To this end, we reiterate our adherence to the Uniform Requirements for Manuscripts Submitted to Biomedical Journals formulated by the International Committee of Medical Journal Editors ${ }^{4}$. We are now available from http://www.psohns.org.ph/pjohns. Our new Editorial Board includes international scholars with impressive publishing records and citation indices. We have an equally august international group of peer reviewers who graciously agreed to help us gratis et amore. This issue features two international source articles. We are especially grateful to friends, alumni and colleagues overseas who choose to publish in our journal rather than in more prestigious, indexed titles. With your support, we trust that the scope and coverage, and quality of editorial work and content of our journal will continue growing in breadth and depth over the next five to eight years.

We are thankful to Natividad Almazan-Aguilar, President of the PSOHNS and its Board of Trustees 2005 for entrusting us with the privilege of serving you through the Philipp J Otolaryngol Head Neck Surg. We trust that future leaders of our Society infuse the journal with the much-needed financial and management support necessary to ensure production quality (layout, printing, graphics, illustrations) and "that services and products of contractors, vendors, and other commercial interests required for proper publication are selected on the basis of merit ${ }^{5 \prime \prime}$. We invite you to consider your vital role in revitalizing our journal: surely it deserves much more than "second-choice" articles and PhP100.00 in annual journal fees?

Through our journal, let us be "informed" of what has "transpired" so that being "inspired," we can work to "transform" ourselves, our colleagues, our patients, our society and our world for the better.

Mabuhay tayong lahat!

Jose Florencio F. Lapeña, Jr., MA, MD 